\title{
Mobile phones and media use in Madang Province of Papua New Guinea
}

\begin{abstract}
ABSTRACI
A mobile phone service was not available to the majority of the population in Papua New Guinea (PNG) until mid-2007. Since that time, commercial competition has been introduced into the mobile telecommunication sector and coverage has spread across many parts of the country. While the focus of this article is on mobile phones, the research has also explored media access and media usage more generally. Analysis in this article adopts the 'circuit of culture' model developed by du Gay et al. (1997). The article is based on data from a survey conducted in 2009 in eight rural villages in Madang Province. The research occurred during the primary stages of mobile phone adoption in these places, providing a rare opportunity to gauge early adoption behaviour and attitudes.
\end{abstract}

Keywords: cell phone, circuit of culture, communication, Melanesia, mobile phone, Papua New Guinea, phone, telephone.

\section{AMANDA WATSON}

Queensland University of Technology

$\mathrm{P}$ APUA NEW GUINEA is the largest nation in the Pacific region, with seven million people (Bourke, 2012). The majority of the PNG population lives in rural areas (National Statistical Office of Papua New Guinea, 2004). Many parts of PNG have only poor infrastructure (Government of Papua New Guinea \& United Nations in Papua New Guinea, 2004, p. 5). Disparate communities are separated by impassable topographical obstacles, such as high mountains, poor roads and open seas. These impediments are reflected in poor performance on development indicators, such as low life expectancy (60.7 years) (United Nations, 2009) and low adult literacy rate (59.1 percent) (United Nations, 2010). There is 
poor access to water, with only 61 percent of people having access to an improved water supply (United Nations, 2007). Papua New Guinea ranks poorly on the United Nations Human Development Index: 137th out of 169 countries (United Nations, 2010). Papua New Guinea gained independence in 1975 (Griffin, Nelson \& Firth, 1979, p. 231; Waiko, 1993, p. 80 \& pp. 125126). Since that time, the country has had a democratic, Westminster style of government (Australian Government Department of Foreign Affairs and Trade, 2013), although elections in some seats have been marred by violence and allegations of corruption (Flower \& Leahy, 2012; Fox, 2012; Perrottet \& Robie, 2011, p. 167).

As landline telephone infrastructure has only very rarely extended beyond urban areas (Jussawalla, 1994, p. 158; also Crocombe, 2001, p. 270), the rapid expansion of mobile phone service to rural areas from mid-2007 (Watson, 2011, pp. 46-48) resulted in much excitement (Watson, 2011, pp. 48-49). This article will show that the anticipated benefits of mobile phone availability were not fully realised in rural areas of PNG, at least in the early days of technology adoption. Obstacles included pricing, difficulties with recharging handset batteries in communities which did not have mains electricity supply, and also concerns about negative social changes related to mobile telephony, for example, parental stress over youth forming unsuitable relationships. While there are manifest possible ways for mobile phone technology to change user communication patterns, in the period immediately following introduction, pricing and other obstacles have hindered the beneficial outcomes which may have been expected by some theorists.

\section{Mobile phones and communication technology scholarship}

Mobile telephony is worthy of academic attention as it 'has a significantly greater degree of impact upon communication activities and practices, with further impacts across the wider society' (Flew, 2007, p. 23) when compared with other communication and media devices such as DVD players. Even so, mobile phone scholarship is a relatively nascent field, with almost no research on mobile phones having been published before the year 2000 (Green \& Haddon, 2009, p. 1). Much of the early mobile phone research was conducted in developed nations (Donner, 2008, p. 140) as mobile phones were widely available there much earlier than in developing nations (Goggin, 2006, p. 1; ITU, 2010).

The Pacific has been one of the last regions of the world to experience 
widespread mobile phone access and uptake. Developing nations in Africa, Asia, the Caribbean and elsewhere have experienced significant growth in mobile telecommunication markets, particularly since 2000 . In the decade between 2000 and 2010, the number of mobile phone users in developing nations increased dramatically (ITU, 2010). Contemporaneous with the growth of mobile phone markets in developing nations, an increasing number of studies is emerging in such countries and proving to be valuable (Donner, 2008, p. 152). Recently, scholarship has focused on whether mobile phones can be harnessed to assist in service delivery and development outcomes (e.g. Chib, Lwin \& Jung, 2009; Chib, 2012; Watson, 2012a).

Mobile phone scholarship is a recent iteration of communication technology research, stretching back to the period following World War II when mass communications theory emerged. Within this body of work, 'the mass media were thought to have a powerful and direct influence on individuals' (Melkote, 2010/2003, p. 110; see also Mansell, 2009, pp. 2-3; Flew, 2007, p. 7). Television and radio were seen as tools for transmitting influential messages to a wide audience (Schiller, 2010/1991, p. 247). Concurrently, development communication theorists and practitioners had 'high hopes that radio and television could be put to use in the world's most disadvantaged countries to bring about dramatic progress' (Paterson, 1997, np).

The current research project fits into the broad framework of communication theory, situated at the forefront of research which is dealing with new communication technologies at the time when these technologies are first becoming available in the field sites. With an understanding of the historical progress of communication theory, starting from mass communications theory, this research project is most closely aligned with the development communication strand of communication theory. Within development communication, there are two main schools of thought: the first associated with mass communications theory and modernisation theory, and the second influenced by the political economy approach and dependency theory (Watson, 2011, pp. 13-15). In the current research project, data preferred by proponents of each of these approaches to development communication were collected: quantifiable indicators of media penetration and access, and qualitative statements sourced from open-ended questions, respectively.

Within the wider communication field, a subset of studies focuses on technology, society and communication. The 'circuit of culture' model was developed by du Gay, et al. (1997) to illustrate five facets of the relationship

158 PACIFIC JOURNALISM REVIEW 19 (2) 2013 
between technology and society: representation, regulation, identity, consumption and production. Interactions between the five components of the model (See Figure 1) contribute to 'the meaning that an artefact comes to possess' (du Gay, et al., 1997, p. 3) in society. The authors argued that the circuit was an important framework 'through which any analysis of a cultural text or artefact must pass if it is to be adequately studied'. This meant examining any technology with respect to "how it is represented, what social identities are associated with it, how it is produced and consumed, and what mechanisms regulate its distribution and use'.

\section{Figure 1: Circuit of culture model}

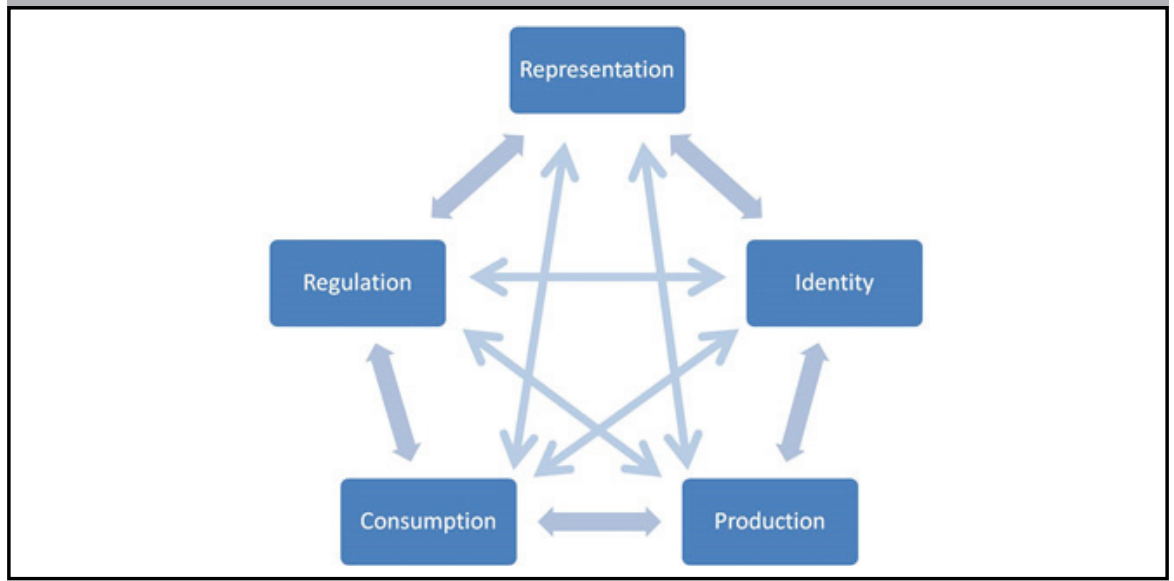

Note: Circuit of culture model (from du Guy et al., 1997, p. 3)

The current research project contributes to the growing body of mobile phone scholarship. It has seized a rare opportunity to study communities in the very earliest stages of their discovery of mobile telephony, and their consideration of whether or how to incorporate mobile phone use into social activities and private lives. Its aim was to assess the role of mobile telephony in rural villages in PNG and to determine whether there may be an intersection between communication and development in this context, particularly as viewed through the eyes of the local residents.

\section{The present research project and research design}

The current research project examines contemporary trends in communication practices in PNG. Specifically, it looks at the recent introduction of 
mobile telephone services into rural areas of the country. The research project has used some of the approaches of development communication theory. Development communication is about development occurring or being attempted, and how this relates to communication activities (Watson, 2011, pp. 13-15). Development communication asks questions like 'Where does the media fit into people's lives and development prospects?'. Radio is typically considered in these types of discussions. In like fashion, the current research project asks 'Where do mobile phones fit into people's lives and development prospects?'. If the mass media are unable to achieve much (both in terms of theoretical limitations of one-way media flows and in terms of the lack of media penetration in rural villages in PNG), then maybe the newly available communication device, the mobile phone, can assist in leading to some form of development. The primary research question addressed by this research is: 'What are the roles of mobile phones in rural villages in PNG?' Related sub-questions include: 'How do rural villagers in PNG describe their feelings about the introduction of mobile telephony?'; 'In what ways are social relationships and roles changing, remaining static or being reinforced as a result of the introduction of mobile phones?'; 'What factors limit or facilitate the uptake and use of mobile phones?'; and 'How many rural villagers are taking up this new technology, and how is it being used?'

The current project explores areas related to development communication scholarship and employs some research approaches used in that field.

\section{The field research}

This article is based on data from a survey conducted in 2009 in eight rural villages in Madang Province. The work was undertaken in these locations as a rather typical socio-economic and geographical landscape of the country. The people there are of a Melanesian culture, one with many characteristics shared across the diverse regions and communities of PNG. All research respondents are living in rural villages where subsistence agriculture is the main economy. The villages are not, in aggregate, 'Papua New Guinea'; this is not a national survey; yet in their composition and identity they are definitely 'of' Papua New Guinea, and of nowhere else. Madang Province was accessible to the researcher, both in cultural terms, through the experience of living and teaching in the province for several years, and in physical terms, where it was possible to manage limited, but strategic travel and strategic distance communication; and above all, where it was possible to engage

160 PACIFIC JOURNALISM REVIEW 19 (2) 2013 
educated young people as research assistants, thus penetrating the communities of their home villages in an accustomed and respectful manner.

The villages listed in Table 1 are from three different districts: Sumkar, Bogia and Rai Coast. In line with early development communication research, there were questions in the survey questionnaire which aimed to ascertain levels of media penetration, media access and media consumption patterns (See also Tacchi, Slater \& Hearn, 2003). In keeping with later notions of development communication, open-ended questions were included in the survey questionnaire in an attempt to enable local voices to express their opinions, desires and concerns.

Research assistants were recruited to conduct survey questionnaires in their home villages. The research assistants were selected from among full-time, undergraduate students at the campuses of Divine Word University in Madang. Desirable candidates were those with prior research training or experience. To be eligible for consideration, students needed to be PNG nationals who hailed from a village which had mobile phone reception, and who were planning to return to that village following the conclusion of the second semester in 2009. The selection criteria used included: the varying types of village locations (for example remote or rural, and coastal, mountain or island); and the availability of mobile phone reception in the village. Table 1 indicates the number of completed survey questionnaires returned by each assistant. The number of blank survey questionnaires given to each assistant was determined based on the number of people in their home village. Although assistants were not always able to complete all the questionnaires as planned, in most cases the desired number of responses was returned.

\section{Table 1: Madang Province research assistants}

\begin{tabular}{|l|c|c|}
\hline Research assistant & Village, District & $\begin{array}{c}\text { Number of survey } \\
\text { questionnaires }\end{array}$ \\
\hline Stellah Kisekol & Yukyuk, Sumkar & 75 \\
\hline Wendy Wuluk & Pepaur, Sumkar & 100 \\
\hline Andrew Sepu & Dangale, Bogia & 80 \\
\hline Martin Bank & Kurum, Sumkar & 80 \\
\hline Sylvester Marep & Giri 2, Bogia & 57 \\
\hline Emmil Yambel & Basamuk, Rai Coast & 42 \\
\hline Matthew Taleo & Lalok, Rai Coast & 74 \\
\hline Almanzo Matbob & Kawe, Sumkar & 66 \\
\hline
\end{tabular}

PACIFIC JOURNALISM REVIEW 19 (2) 2013161 
The sample includes mountain, island and coastal villages. Yukyuk is a coastal village located on Karkar Island. Pepaur is a coastal village on the main road outside of Madang, with daily access to buses for the three-hourlong trip to town. The people from the village of Dangale on Manam Island were evacuated from the island due to a volcanic eruption in 2004 (ABC, 2005) and at the time of the survey were living in Asuramba care centre, located on the main road, three-and-a-half hours by bus from Madang. Kurum and Giri 2 are both inland villages.

At Basamuk, a processing plant was established after 2008 for a large nickel mine (Ramu Nico Management (MCC) Limited, nd-a; Ramu Nico Management (MCC) Limited, nd-b; McDonald, 2007), following earlier exploratory drilling from around 2002. Where previously there were mainly subsistence farmers, people from Basamuk became able to gain employment with the mine. Basamuk and Lalok are both coastal villages. Kawe is also a coastal village, in the Rempi area.

The research was conducted in October and November 2009, which was during the early days of mobile phone adoption in these places.

\section{Findings}

The article reviews the data from the eight villages to ascertain common trends. The statistics provided here are for 574 respondents in total. Most of the respondents did not have electricity at home (478 people, or 83.3 percent of respondents). Of those with power, the most common power source was a generator, although a third of houses with generators did not have fuel for the generator present at the time when the survey was conducted. Other forms of power, in rather few cases, were mains power supply and solar systems. The use of kerosene lamps for lighting was extremely common (506 people, or 88.2 percent). No-one had a landline phone or internet connection at home. Seven people (1.2 percent) had a computer at home. Forty four people (7.7 percent) had a television at home. Nearly half of the respondents (43.6 percent) had a working radio receiver in their home.

There were more male respondents $(338$, or 58.9 percent) than female ( 228 , or 39.7 percent), while eight people did not answer the question (1.4 percent). The sample was skewed towards youth, with nearly half of the respondents aged between 16 and 30 (273, or 47.6 percent). While it may be expected that younger people would be leaders in coming forward and talking about mobile phones, and while it is acknowledged that some of the

162 PACIFIC JOURNALISM REVIEW 19 (2) 2013 
research assistants were more inclined to talk to people closer to their own young age group than to older villagers, the overall age range is nonetheless consistent with general demographic patterns. In PNG, the life expectancy at birth is 60.7 years (United Nations, 2009), and therefore it is reasonable that only 5.2 percent of survey respondents (or 30 people) were over 60 years of age. Similarly, the probability of not surviving to age 40 in PNG is 15.9 percent (United Nations, 2009), which again correlates to the comparatively low number of respondents aged over 40 in this sample compared to what might be expected of a representative sample in a more developed country.

About half of the respondents owned a mobile phone $(288$, or 50.2 percent), although this varied greatly between villages; for example, only 32.5 percent of respondents in Dangale owned a mobile phone, whereas 88.1 percent of those from Basamuk were owners. There was low usage overall, when looking at calls and text messages on the preceding day. Across the eight villages, the average number of phone calls made in a day by mobile phone owners was one and the median was zero. The average number of text messages sent in a day was one and the median was zero. Considering just mobile phone owners in the youngest age bracket (aged 16 to 30 years; $\mathrm{n}=163$ ), the average number of calls made in a day was one, with a median of zero and the average number of text messages sent in a day was two, with a median of zero.

The most common benefits of mobile phones were seen as social: it was easier to talk to family members and friends residing a long way away, and communication in general was easier. The social value of the mobile device far outweighed the perception of other benefits, such as use in emergencies and business transactions. The figures shown in Table 3 are indicative of the number of times the most common benefits were mentioned. This was an

\section{Table 2: Madang Province perceptions of mobile phones}

\begin{tabular}{|l|c|c|}
\hline & Frequency & Percent \\
\hline Not good & 61 & 10.6 \\
\hline Good & 288 & 50.2 \\
\hline Both good and bad & 216 & 37.6 \\
\hline I don't know & 8 & 1.4 \\
\hline No answer & 1. & 0.2 \\
\hline Total & 574 & 100.0 \\
\hline
\end{tabular}

PACIFIC JOURNALISM REVIEW 19 (2) 2013163 


Table 3: Madang Province perceived benefits of mobile phones
\begin{tabular}{|l|c|}
\hline Benefits & Frequency \\
\hline Easy to talk to family and friends a long way away & 170 \\
\hline Easier communication & 162 \\
\hline Quicker communication & 42 \\
\hline Emergency use (not specifically medical) & 36 \\
\hline Can notify people if there is a funeral or other crisis & 29 \\
\hline Development & 28 \\
\hline Business calls & 27 \\
\hline Helps rural people & 24 \\
\hline Costs less money than travelling to convey a message & 17 \\
\hline Can ring ambulance/hospital & 14 \\
\hline Easier than travelling to convey a message & 13 \\
\hline Can send messages to ask for assistance & 13 \\
\hline
\end{tabular}

open question in the survey and respondents were allowed to provide as many responses as they wished. Some people stated no benefits of mobile telephony, whereas others listed several.

Most of the people without mobile phones had not had one before ( 252 people, or 88.1 percent of non-owners). The non-owners were fairly evenly divided between intending to get a mobile phone, not planning to get one, and not being sure. About two-thirds of non-owners said they did not use phones (181 people, or 63.3 percent of non-owners). Those who did tended to ring rarely, or less than five times a month. They usually used mobile phones belonging to relatives and they were usually allowed to do this free of charge. When asked to pay, they usually bought their own flex card (a card containing mobile phone credit) to key into the handset.

About a quarter of respondents lived in a house where no-one owned a mobile phone (142 people, or 24.7 percent of respondents), and another quarter lived in a house where there was only one mobile phone (140, or 24.4 percent). Nokia handsets were by far the most popular, with 185 of the 288 mobile phone owners (or 64.2 percent of mobile phone owners) possessing a Nokia. Most common Nokia makes were Nokia 1202 and Nokia 1200. Over half of the handsets had been purchased in Madang town (165, or 57.3 percent), one main outlet, Ela Enterprises being the most popular store for purchasing mobile phones.

164 PACIFIC JOURNALISM REVIEW 19 (2) 2013 
Half of the respondents viewed mobile telephony in a positive light, while a small number viewed the new service negatively, and the remainder expressed mixed feelings, as is shown in Table 2.

Relatives in PNG urban centres were most commonly phoned, usually to check on them. None of the mobile phone owners had used the mobile phone banking service of Bank of South Pacific (BSP SMS Banking) which was available before the data collection commenced. One respondent had used Nasfund TextBal, a service provided by a superannuation company. Only 13 out of 288 mobile phone owners (or 4.5 percent) had used PNG Power Easipawa Easipay, which is a method for remotely purchasing mains power. The most popular handset features were: the torch; sending and receiving telephone credit; checking the time; the alarm clock; the calendar; games; and the calculator Only 19 mobile phone owners (or 6.6 percent of owners) had used a camera in a handset. The most common method for charging mobile phones was to use a generator in the home village. The cost ranged from no charge through to three Kina or even more (1 PNGK = AUD 0.488; xe.com, 16.8.13). Most people paid nothing, one Kina or two Kina.

The most common negatives expressed were concerns about the money spent; beliefs these devices were increasing adultery and sexual promiscuity; and concerns about criminals (commonly referred to as raskols) using mobile phones to plan illegal activities such as roadside hold-ups and thefts. In Table 4 , the figures are indicative of the number of occasions the most common issues were raised. Some respondents raised numerous objections to mobile telephony, whereas others did not mention any negatives.

When asked why mobile phone reception came to the village, the most common reason given was to make life easier for villagers (233, or 40.6 percent). Money for phone credit commonly came from family members or was Table 4: Madang Province negatives associated with mobile phones

\begin{tabular}{|l|c|}
\hline & Frequency \\
\hline Monetary concerns & 173 \\
\hline Adultery and promiscuity & 147 \\
\hline Raskols & 96 \\
\hline Youth-related issues (mainly discipline issues and lack of focus on schoolwork) & 26 \\
\hline Hard to charge battery with no electricity at home & 12 \\
\hline Health effects of radiation & 9 \\
\hline Pornographic images & 4 \\
\hline
\end{tabular}

PACIFIC JOURNALISM REVIEW 19 (2) 2013165 
generated from market activities. Paid work was represented at a significant though far from dominant level, with 78 of the mobile phone owners (or 27.1 percent of owners) having bought their mobile phone using money from paid work. About a fifth of mobile phone owners (62 mobile phone owners, or 21.5 percent) did not receive telephone credit from others. Those in paid employment mainly bought their own credit and were less likely than other mobile phone owners to receive credit from other people, as was shown in a Pearson chi-square test (Moore, McCabe \& Craig, 2009, p. 531) $(n=288$ mobile phone owners). The test showed very strong evidence of dependence, at 1 percent statistical significance ( $p$-value $<0.001$ ), between paid employment and not receiving mobile phone credit.

To determine whether a person's gender had any bearing on whether or not they were likely to own a mobile phone, a Pearson chi-square test (Moore, et al., 2009, p. 531) was performed on the dataset from the eight villages. Eight respondents were not included in this test as their gender was not indicated on the returned survey questionnaires. Thus, the total number of cases tested was 566 in this instance. From the test, there was very strong evidence of dependence, at 1 percent statistical significance ( $p$-value $<0.001)$, meaning that gender related to mobile phone ownership. The data indicated that males were more likely to own mobile phones than females. The Pearson chi-square test (Moore, et al., 2009, p. 531) was also performed to assess whether age related to the likelihood of a person owning a mobile phone $(n=574)$. There was very strong evidence of dependence, at 1 percent statistical significance (p-value $<0.001$ ), meaning that age did relate to mobile phone ownership. The data indicated that young people aged 16 to 30 were more likely to own mobile phones than older people.

General conditions of life were sparse. In the eight villages, people were drawing water from a range of different sources. In decreasing order, the common ones were: wells, springs, creeks, fast-flowing rivers, and tanks. Ten percent of respondents did not have access to a toilet. The rest did, with most of them using pit toilets, and a very small number of people having septic toilets ( 6 people, or 1.0 percent). Most people had at some point in their lives listened to the radio or watched a movie. Forty four people ( 7.7 percent) had used a computer during their lifetime. Only 13 people ( 2.3 percent) had used the internet and only 12 people (2.1 percent) had used email. Nearly two-thirds of respondents had been to another province at some point in their lives, but only six people (1.0 percent) had travelled to another country.

166 PACIFIC JOURNALISM REVIEW 19 (2) 2013 


Table 5: Madang Province respondents' media access per month
\begin{tabular}{|l|c|c|c|}
\hline & Yes/No & Frequency & Percent \\
\hline Radio & Yes & 435 & 75.8 \\
\hline Letter sent & Yes & 47 & 8.2 \\
\hline Letter received & Yes & 68 & 11.8 \\
\hline Television & Yes & 187 & 32.6 \\
\hline Movie & Yes & 300 & 52.3 \\
\hline Newspaper & Yes & 2321 & 40.4 \\
\hline Magazine & Yes & 90 & 15.7 \\
\hline Book & Yes & 365 & 63.6 \\
\hline
\end{tabular}

Table 5 shows those respondents who had used various forms of media in the month before they were surveyed. Listening to the radio and reading a book were common activities, whereas it was rare to engage in written correspondence or read a magazine. Computer usage was rare.

About half of respondents had been to Madang (the town which is also the capital of Madang Province) in the preceding month (310, or 54.0 percent). The frequency of this travel was hugely variable, with people from some places not having travelled much (Yukyuk 30.7 percent and Pepaur 41.0 percent), but people from other villages having been to town in large numbers during the time period in question (Kawe 78.8 percent, and Lalok 63.2 percent). It was most common for people to have left school at the end of grade 6 (182 people, or 31.7 percent). Only a small number of people had completed high school (24 people, or 4.2 percent). Most people had not engaged in any further education ( 485 people, or 84.5 percent) and only 8 people (1.4 percent) had been to university.

In summary, the findings regarding mobile phones indicated that respondents felt mobile phones were generally a positive force for change in rural parts of PNG, enabling improved communication with relatives in other parts of the country, but they created a cost burden for people leading a predominantly subsistence lifestyle, and they were linked to negative social changes that caused concern for villagers. With reference to media usage, the survey highlighted a paucity of access to numerous news media, with the exception of radio broadcasting. The survey also showed very limited access to computers, internet and email in rural villages. 


\section{Discussion}

Although there were variations between villages and key situational differences, such as the mine site next to Basamuk or the people from Manam Island living in care centres, the findings in relation to mobile telephony and media usage indicated there were commonalities across the province. In particular, the main benefits and key negative concerns articulated around mobile phones were commonly felt throughout rural areas: respondents were pleased about the social applications of mobile telephony but were concerned about the money spent, as well as social changes perceived to be occurring in terms of sexual and criminal behaviour.

Interactions between the five components of the 'circuit of culture' designed by du Gay, et al. (shown in Figure 1) show 'the inescapable articulations among spheres that jointly bring a cultural artefact to life' (Goggin, 2006, p. 14). It is through these interactions that 'the meaning that an artefact comes to possess' (du Gay, et al., 1997, p. 3) evolves and emerges in society (Green $\&$ Haddon, 2009, p. 3). As the five elements in the model 'continually overlap and intertwine in complex and contingent ways' (du Gay, et al., 1997, p. 4), no particular element is more important than the others.

In PNG, government regulatory decisions regarding licensing and competition were key precursors to the expansion of mobile phone services into rural areas (Watson, 2011, pp. 250-253). While government regulations can be influential (Green \& Haddon, 2009, p. 5), the term 'regulation' can also refer to societal, institutional or individual responses to any change which is viewed 'as a threat to order and to established patterns of conduct' (du Gay, et al., 1997, p. 117; also Green \& Haddon, 2009, pp. 68-70). Thus, the banning of mobile phones from some schools in PNG (Watson, 2011, p. 248) is a clear example of regulation, responding to concerns about the perceived proliferation and dissemination of inappropriate images through students' handsets.

In the early stages of mobile phone network expansion into rural areas of PNG, survey respondents enunciated particular worries about the technology 'reflecting an unwanted shift in cultural values' (Campbell, 2006, p. 142), for example with young people using mobile phones to communicate with potential partners, thus avoiding traditional checks on courting processes. It is likely that the development of social codes around acceptable behaviours (Goggin, 2006, p. 39) will emerge through negotiations within such communities over time.

168 PACIFIC JOURNALISM REVIEW 19 (2) 2013 
Churchill \& Wakeford (2002) have emphasised the importance of the element of representation in the model provided by du Gay, et al., particularly representation through advertising. Advertising of mobile telephony in PNG has been very prominent since mid-2007, with many billboards and newspaper advertisements displaying the colours of the telecommunication companies. Broadcast media have included paid advertisements as well as sponsorship of news broadcasts and other programmes by mobile phone providers.

While the paucity of media access evidenced in this research suggests that much of the advertising may have been beyond the life experience of most rural people in PNG, the term 'representation' as it is used in the model by du Gay, et al. can also refer to representations of a technology 'in language, in discourse and in the concepts and ideas in our heads' (du Gay, et al., 1997, p. 40). Thus, the findings regarding the perceptions of rural villagers about the advantages and disadvantages of mobile telephony in their lives and communities present 'representation' of the mobile phone by these people. Their mixed responses, explaining both positive and negative consequences of mobile telephony, were similar to findings in Asia (Bell, 2005, pp. 71-80), and in Sudan (Brinkman, de Bruijn \& Bilal, 2009, p. 69). Linked to these findings, the notion of 'identity' in the model refers to the 'various groups and types of people [who] came to be associated with' (du Gay, et al., 1997, p. 4) the technology, and in this case that principally refers to relatives, adulterers, young people, and raskols.

The technical production process of designing and manufacturing a mobile phone handset or tower is beyond the scope of the present research project, though it should be noted that both are important background factors: very cheap handsets were marketed from the outset, while maintaining major infrastructure incurs premium costs in remote PNG, as a poorly developed country with difficult terrain. Linked closely with production is the concept of 'consumption', which refers to how technologies are consumed, or in other words, what people do with them (du Gay, et al., 1997, p. 5). Findings related to consumption found lower patterns of usage for phone calls, text messaging and mobile phone banking than may have been expected. As relatives in urban centres in other parts of PNG were the most common phone call recipients, findings about usage (or 'consumption') were also closely tied to understandings of 'identity'. While in the early days of access in rural areas of PNG mobile phones may not have yet reached a situation where they became socially regulated, normal components of everyday life, Mante \& 
Heres suggest that consumption and use of new technologies will become normalised and integrated into everyday behaviours through the final stages of adoption (p. 128).

The survey established that villagers had limited access to media output and extremely limited access to computers. They generally travelled reasonably often to urban centres, but much less often to other provinces or countries. Radio broadcasting has been found to be more commonly used in the sample villages than other forms of media. This finding is in keeping with other scholarship which has found radio to be the most accessible medium in PNG (Anderson, 2007, pp. 106-107; Duffield, Watson \& Hayes, 2008; InterMedia et al., 2012, p. 10; Matbob, McManus \& Papoutsaki, 2011, p. 6). It has also been suggested that 'radio is the most suitable medium of mass communication in PNG because it corresponds better to the oral traditions of the country' (Rooney, Papoutsaki \& Pamba, 2004, p. 3; also Issimel, 2011, p. 149). Even so, there are problems with radio reception being crackly and unclear in some places (InterMedia, et al., 2012, p. 10) and with government-run radio stations being off-the-air or unable to meet the needs of listeners (Issimel, 2011, p. 155; Matbob, et al., 2011, p. 6; Boden, 1995).

Few people regularly read newspapers and this finding matches previous research about media in PNG which suggested 'newspapers rarely circulate outside of urban areas so the vast majority of Papua New Guineans are excluded from information' (Rooney, et al., 2004, p. 4; also Crocombe, 2001, p. 139; InterMedia et al., 2012, p. 10; Matbob, McManus \& Papoutsaki, 2011, p. 6). Not only is newspaper distribution limited, due to logistical impediments and high transportation costs, but also 'high rates of illiteracy make newspapers inaccessible to many people, not to mention that the cost of a daily newspaper is not affordable for poor people' (Rooney, et al., 2004, p. 7; also InterMedia, et al., 2012, p. 10; for literacy rates, Perrottet \& Robie, 2011, p. 166).

In line with the present findings, other authors have also established that internet access in PNG is very low (Duffield, et al., 2008; Perrottet \& Robie, 2011, p. 166). This situation is changing, with increasing numbers of people engaging in social media, either through mobile phone handsets or computers (Cave, 2012; InterMedia, et al., 2012, p. 10; Logan, 2012; Matbob, 2011, p. 27; Narokobi, 2011; Perrottet \& Robie, 2011, pp. 166-167; Thomas, 2011, p. 46).

For years, PNG has only had one television station. A newly established second television broadcaster is struggling to extend its broadcast reach

170 PACIFIC JOURNALISM REVIEW 19 (2) 2013 
beyond urban areas (InterMedia,et al., 2012, p. 13; Thomas, 2011, p. 30) or to broadcast sufficient local content (Manek, 2010, p. 57). Some homes have access to additional television channels from other countries (Manek, 2010, p. 57). Radio has typically been 'more accessible and more affordable than television' (Thomas, 2011, p. 30; also InterMedia, et al., 2012, p. 10). While the situation is changing in PNG, television consumption and internet access tend to be limited to urban elites (InterMedia, et al., 2012, p. 10).

Development communication practitioners might do well to focus on radio and mobile phones in PNG, as these generally have wider reach and more accessibility than other media (InterMedia, et al., 2012). Indeed, divisions between media are breaking down, with people listening to radio through mobile phone handsets and newspaper headlines being sent by text messaging to subscribers' mobile phone handsets (a service offered by PNG's Post-Courier since 2013). Rural villagers have also been calling town-based relatives for information sourced from the internet during tsunami alerts (Watson, 2012b).

\section{Conclusion}

While this research is primarily focused on mobile phones, it also provides contextual information about access to and use of media in rural villages of Madang Province in PNG. The survey reported on in this article was conducted during the early days of access to mobile phone reception in rural areas of PNG. The timing provided a unique window of insight into early adopter attitudes and behaviours. Given the country's well-documented diversity (Reilly, 2004, p. 480), it could be suggested that research conducted in only one province is unlikely to provide insights into attitudes and experiences elsewhere in PNG. On the other hand, the consistency in responses across villages, coupled with the differences in landscape and context within the sample group which includes island, mountain and coastal villages, suggest that some useful inferences can be made regarding mobile phone uptake in rural areas across PNG.

The research shows that anticipated usage and benefits of mobile phone availability - the 'consumption' factor in the du Gay, et al. model — fell short of reasonable, intuitive and general expectations in rural areas of PNG, during the early stage of adoption of the technology. Draw-backs to wider adoption were: economic costs of the telephone services to poor people, obstacles to recharging batteries, and fears of negative social change, like parents' concerns 
over to whom their children would be talking. Among the factors envisaged by du Gay, et al., mobile telephony is seen to be finding its place, though not yet in this decade as a dominant element creating leading, terminal changes or imbalances. On the other hand, this technology is known from global experience to have the properties of a potent instrument of economic and social change, and the scale of investment in the industry suggests that it has substantial potential to create more impact.

With network coverage expanding and with technological advances continuing, a strong argument could be made for further research to be undertaken in the same eight villages at a later date. Such research would provide a meaningful comparison and an opportunity for longitudinal analysis.

\section{References}

ABC. (2005). NZ boosts aid funding to PNG island homeless [website]. Retrieved May 2, 2013, from http://www.abc.net.au/news/stories/2005/07/14/1413859.htm Anderson, K. (2007). Whither Pacific 'traditional' media? Internet technology in political education and participation. Pacific Journalism Review, 13(2), 94-111.

Australian Government Department of Foreign Affairs and Trade. (2013). Papua New Guinea country brief. Retrieved May 1, 2013, from http://www.dfat.gov.au/geo/ png/png_brief.html

Bell, G. (2005). The age of the thumb: A cultural reading of mobile technologies from Asia. In Thumb culture: The meaning of mobile phones for society, eds. P. Glotz, S. Bertschi \& C. Locke, pp. 67-87. New Brunswick, USA: Transaction Publishers. Boden, I. (1995). Time to light up the NBC airwaves. Pacific Journalism Review, 2(1). Bourke, M. (2012, July 3). PNG's population predictions compared with preliminary 2011 census data [blogpost]. Retrieved May 1, 2013, from http://pacificinstitute.anu. edu.au/outrigger/2012/07/03/pngs-population-predictions-compare-2011-census/

Brinkman, I., de Bruijn, M., \& Bilal, H. (2009). The mobile phone, 'modernity' and change in Khartoum, Sudan. In Mobile phones: The new talking drums of everyday Africa, eds. de Bruijn, I., Nyamnjoh, F., \& Brinkman, I. pp. 69-91. Leiden: Langaa and African Studies Centre.

Campbell, H. (2006). Texting the faith: Religious users and cell phone culture. In The cell phone reader: Essays in social transformation, eds. A. Kavoori \& N. Arceneaux, 139-154. New York: Peter Lang.

Cave, D. (2012). Digital islands: How the Pacific's ICT revolution is transforming the region. November 21. Lowy Institute for International Policy. www.lowyinstitute.org

Chib, A., Lwin, M. O., \& Jung, Y. (2009). Adoption of mobile phones to enhance healthcare: A technology acceptance study of maternal care workers in Indonesia. Media Asia, 36 (4), 216-222.

172 PACIFIC JOURNALISM REVIEW 19 (2) 2013 
Chib, A. (2012). The promise and peril of mHealth in developing countries. Mobile Media and Communication, 0(0), 1-7.

Churchill, E., \& Wakeford, N. (2002). Framing mobile collaborations and mobile technologies. In Wireless world: Social and interactional aspects of the mobile age, eds. Brown, B., Green, N., \& Harper, R. 154-179. London: Springer.

Crocombe, R. (2001). The South Pacific. Suva: University of the South Pacific.

Donner, J. (2008). Research approaches to mobile use in the developing world: A review of the literature. The Information Society, 24(3), 140-159.

du Gay, P., Hall, S., Janes, L., Mackay, H., \& Negus, K. (1997). Doing cultural studies: The story of the Sony Walkman. London: Sage Publications.

Duffield, L., Watson, A. H. A., \& Hayes, M. (2008). Media and communication capacities in the Pacific region. eJournalist, 8(1), 20-34.

Flew, T. (2007). Understanding global media. Hampshire: Palgrave Macmillan.

Flower, S., \& Leahy, J. (2012, March 30). The 2012 national elections in Papua New Guinea: Averting violence [website]. Retrieved May 1, 2013, from http:// www.lowyinstitute.org/publications/2012-national-elections-papua-new-guineaaverting-violence

Fox, L. (2012). Fraud, violence cloud PNG election [Website]. Retrieved May 1, 2013, from http://www.abc.net.au/news/2012-06-24/fraud-violence-cloud-pngelection/4089364

Goggin, G. (2006). Cell phone culture: Mobile technology in everyday life. London: Routledge.

Government of Papua New Guinea and United Nations in Papua New Guinea. (2004). Papua New Guinea-Millennium development goals progress report 2004.

Green, N., \& Haddon, L. (2009). Mobile Communications: An introduction to new media. Berg New Media Series. Oxford: Berg.

Griffin, J., Nelson, H., \& Firth, S. (1979). Papua New Guinea: A political history. Richmond, Victoria: Heinemann Educational Australia.

InterMedia, NBC, ABC international development and AusAID. (2012). Citizen access to information in Papua New Guinea: Citizen survey, June 2012.

Issimel, A. (2011). Radio Madang: Tuned in for development? In Communication, culture and society in Papua New Guinea: Yu Tok Wanem?, edited by Papoutsaki, E., M. McManus \& P. Matbob. DWU Press, Madang, pp. 147-156.

ITU. (2010). World telecommunication/ICT indicators database: Mobile telephony. International Telecommunications Union: Retrieved February 26, 2011, from http:// www.itu.int/ITU-D/ict/statistics/index.html

Jussawalla, M. (1994). Pacific Island nations. In Telecommunications in the Pacific basin: An evolutionary approach, eds. E. Noam, S. Komatsuzaki \& D. A. Conn, pp. 155-176. New York: Oxford University Press.

Logan, S. (2012). Rausim! Digital politics in Papua New Guinea. SSGM Discussion Paper 2012/9. State, society and governance in Melanesia. Australian National University.

Manek. C. (2010). Freedom of information-Challenges and the way forward. Pacific Journalism Review 16(2), 56-61.

PACIFIC JOURNALISM REVIEW 19 (2) 2013173 
Mansell, R. (2009). Introduction to Volume 1. In The information society: Critical concepts in sociology, ed. R. Mansell, 1-11. London: Routledge.

Mante, E., \& Heres, J. (2003). Face and place: The mobile phone and internet in the Netherlands. In Machines that become us: The social context of personal communication technology, ed. J. E. Katz, pp. 127-146. New Brunswick, USA: Transaction Publishers.

Matbob, P., McManus, M., \& Papoutsaki, E. (2011). Supporting communication research in Papua New Guinea. In Communication, culture and society in Papua New Guinea: Yu Tok Wanem?, eds. E. Papoutsaki, M. McManus \& P. Matbob. DWU Press, Madang, pp. 1-18.

Matbob, P. (2011). The state of investigative journalism and the growing impact of new media. In Communication, culture and society in Papua New Guinea: Yu Tok Wanem?, eds. E. Papoutsaki, M. McManus \& P. Matbob. DWU Press, Madang, pp. 20-29.

McDonald, H. (2007). China nickel development threatens values, traditions. Retrieved September 21, 2010, from http://www.theage.com.au/news/business/ china-nickel-development-threatens-values-traditions/2007/07/13/1183833776332. html?page=fullpage\#contentSwap2

Melkote, S. R. (2010/2003). Theories of development communication. In international communication: A reader, ed. D. K. Thussu, pp. 105-121. London: Routledge (first published in 2003).

Moore, D. S., McCabe , G. P., \& Craig, B. A. (2009). Introduction to the practice of statistics: Extended version. 6th ed. New York: W. H. Freeman and Company.

Narokobi, E. (2011). Digicel releases the Facebook phone. Masalai blog. Retreived January 15, 2013, from http://masalai.wordpress.com/2011/12/03/digicel-releasesthe-facebook-phone/

National Statistical Office of Papua New Guinea. (2004). Population and social statistics. Retreieved October 15, 2008, from http://www.spc.int/prism/country/ pg/stats/Pop_Soc_percent20Stats/popsoc.htm

Paterson, C. (1997). Development communication. Museum of Broadcast Communications. Retrieved May 20, 2010, from http:/www.museum.tv/archives/etv/D/ htmlD/developmentc/developmentc.htm

Perrottet, A., \& Robie, D. (2011). Pacific media freedom (2011): A status report. Pacific Journalism Review 17(2), 148-186.

Ramu Nico Management (MCC) Limited. (nd-a). Key dates \& events. Retrieved September 21, 2010, from http://www.ramunico.com/plus/view.php?aid=745

Ramu Nico Management (MCC) Limited. (nd-b). Ramu Nico Introduction. Retrieved September 21, 2010, from http://www.ramunico.com/plus/view.php?aid=1133

Reilly, B. (2004). State functioning and state failure in the South Pacific. Australian Journal of International Affairs, 58 (4), 479-493.

Rooney, D., Papoutsaki, E., \& Pamba, K. (2004). A country failed by its media: A case study from Papua New Guinea. In 13th AMIC Annual Conference, 'Impact of New \& Old Media on Development in Asia', Bangkok, Thailand, July 1-3.

174 PACIFIC JOURNALISM REVIEW 19 (2) 2013 
Schiller, H. I. (2010/1991). Not yet the post-imperialist era. In International communication: A reader, ed. D. K. Thussu, 247-260. London: Routledge (first published in 1991).

Tacchi, J. A., Slater, D., \& Hearn, G. (2003). Ethnographic action research: A user's handbook developed to innovate and research ICT applications for poverty eradication. New Delhi: UNESCO.

Thomas, V. (2011). Yumi Piksa-Developing a community-responsive way of filmmaking in Melanesia. Pacific Journalism Review 17(2), 27-49.

United Nations. (2007). 2007/2008 Human development report; Papua New Guinea, Retrieved April 21, 2008, from factsheet. http://hdrstats.undp.org/countries/country_fact_sheets/cty_fs_PNG.html

United Nations. (2009). Human development report 2009: Papua New Guinea. Retrieved April 27, 2010, from http://hdrstats.undp.org/en/countries/country_fact sheets/cty_fs_PNG.html

United Nations. (2010). Human development report 2010: Papua New Guinea. Retrieved February 28, 2011, http://hdrstats.undp.org/en/countries/profiles/PNG. html

Waiko, J. (1993). A short history of Papua New Guinea. Melbourne: Oxford University Press.

Watson, A. H. A. (2011). The mobile phone: The new communication drum of Papua New Guinea. Unpublished PhD thesis, Queensland University of Technology. Retrieved December 5, 2011, from http://eprints.qut.edu.au/47170/

Watson, A. H. A. (2012a). Could mobile telephony be harnessed for development in Papua New Guinea? Contemporary PNG Studies: DWU Research Journal, 17, 46-52,

Watson, A. H. A. (2012b). Tsunami alert: The mobile phone difference. The Australian Journal of Emergency Management, 27 (4), 44-48.

Dr Amanda H A Watson completed her doctoral research at Queensland University of Technology with support from Divine Word University. Dr Watson is mobile communications research consultant with the Papua New Guinea Economic and Public Sector Programme and is affiliated with the Centre for Health Communication at the University of Technology, Sydney. A brief outline of these findings was presented at ANZCA 2012, the conference of the Australian and New Zealand Communication Association, 4-6 July 2012, Adelaide, Australia. ahawatson@hotmail.com 